\title{
ANALISIS SISTEM DAN PROSEDUR PENGELOLAAN KEUANGAN PEMERINTAH DAERAH DENGAN MENGGUNAKAN APLIKASI SISTEM INFORMASI MANAJEMEN DAERAH (SIMDA) DALAM PENYUSUNAN LAPORAN KEUANGAN PADA BADAN PENGELOLA KEUANGAN DAN ASET DAERAH KABUPATEN MUSI BANYUASIN
}

\author{
Masri Ermawijaya \\ Program Studi S1 Akuntansi STIE Rahmaniyah Sekayu \\ Email: masriermawijaya60@gmail.com
}

\begin{abstract}
ABSTRAK
Penelitian ini bertujuan untuk mengetahui sistem dan prosedur pengelolaan keuangan dengan menggunakan Aplikasi Sistem Informasi Manajemen Daerah (SIMDA), dalam penyusunan laporan keuangan Pada Badan Pengelola Keuangan dan Aset Daerah Kabupaten Musi Banyuasin. Metode yang digunakan dalam penelitian ini adalah metode kualitatif dengan teknik pengumpulan data berupa wawancara dengan tenaga operator aplikasi SIMDA dan dokumentasi berupa sistem dan prosedur dalam pengelolaan keuangan Pemerintah Daerah Kabupaten Musi Banyuasin. Hasil penelitian menunjukkan bahwa dalam Dalam Sistem dan Prosedur pelaporan keuangan sudah berjalan dengan baik namun dalam mengoperasikan Aplikasi SIMDA masih terdapat kendala yaitu lemahnya jaringan, perangkat dan menu dalam komputer yang tersedia tidak sesuai dengan menu aplikasi SIMDA, dan kurangnya tenaga skill yang mengoperasikan Aplikasi SIMDA. Upaya yang dilakukan agar Penyusunan laporan keuangan sesuai dengan aturan dan penerapan dalam Aplikasi SIMDA yaitu dengan cara penyempurnaan dan peningkatan jaringan, seperti disediakannya perangkat komputer yang cukup dan memadai di seluruh perangkat daerah dan Badan Pengelola Keuangan dan Aset Daerah adalah Server nya pelaporan keuangan bagi Perangkat Daerah (PD) Kabupaten Musi Banyuasin, peningkatan versi komputer yang lebih canggih dan mendukung efektivitas pelaporan keuangan, adanya peningkatan bimbingan teknis dan pembinaan bagi tenaga operator dalam pengoperasian Aplikasi SIMDA, sehingga kekeliruan dalam penginputan data, proses dan pelaporan dapat diminimalisir.
\end{abstract}

Kata Kunci : Sistem, Prosedur dan Sistem Informasi Manajemen Daerah (SIMDA) 


\section{PENDAHULUAN}

\subsection{Latar Belakang Masalah}

Laporan Keuangan merupakan alat pertanggungjawaban pemerintah terhadap publik. Dalam proses akuntansi laporan keuangan merupakan proses akhir dari proses akuntansi. Laporan Keuangan dapat digunakan sebagai dasar dalam menyusun Anggaran tahun berikutnya dan berfungsi sebagai alat perencanaan dan pengendalian dalam mengambilan keputusan secara cepat dan akurat.

Akuntansi merupakan Proses pengidentifikasian, pengukuran, pencatatan, dan pengkomunikasian kejadian-kejadian ekonomi suatu organisasi kepada para pemakai informasi yang berkepentingan (termasuk instansi pemerintah). Sebelum penerapan penggunaan aplikasi SIMDA Keuangan yang terintegrasi. Pelaporan Keuangan di BPKAD sudah menggunakan aplikasi SIMDA sebagai alat untuk memepermudah dalam penyusunan laporan keuangan, namun pengelolaannya masih belum terintegrasi antara perangkat daerah dengan BPKAD sebagai server pelaporan keuangan Pemerintah Daerah Kabupaten Musi Banyuasin. Sehingga laporan keuangan dalam hal ini Laporan Realisasi Aggaran dari Perangkat Daerah perlu di input ulang kedalam aplikasi SIMDA pada BPKAD. Untuk menghindari penginputan ulang dan keseragaman akun-akun dalam nomenklatur Laporan Keuangan Pemerintah Daerah, maka diperlukan sebuah sistem yang terintegrasi sehingga pengerjaan pelaporan keuangan oleh tenada administrator Aplikasi SIMDA. Operator Aplikasi SIMDA hanya perlu menganalisis dan mengevaluasi kebenaran penempatan akun-akun sehingga Laporan keuangan yang disajikan oleh Perangkat Daerah telah sesuai dengan pedoman dalam penerapan Aplikasi SIMDA pada Badan Pengelola Keuangan dan Aset Daerah Kabupaten Musi Banyuasin.

Sistem Informasi Manajemen Daerah (SIMDA) keuangan dirancang oleh BPKP merupakan suatu sistem informasi yang dibangun, dikembangkan dan digunakan untuk melakukan proses penyusunan Anggaran Pendapatan dan Belanja Daerah (APBD) berbasis kinerja. Pemerintah daerah beserta Perangkat 
Daerah (PD) diwajibkan untuk menyusun laporan keuangan sebagai bentuk petanggungjawaban pengelolaan keuangan.

Sesuai Undang-Undang Nomor 32 tahun 2004 tentang pemerintah daerah sebagai berikut Otonomi daerah adalah hak, wewenang, dan kewajiban daerah otonom untuk mengatur dan mengurus sendiri urusan pemerintahan dan kepentingan masyarakat setempat sesuai dengan peraturan perundang-undangan.

Diperkenalkannya asas akuntabilitas berorientasi hasil (Result Oriented Accountability) atau istilah akuntabilitas kinerja (Performance Accountability) dan transparansi (Transparency) dalam pengelolaan keuangan negara yang merupakan wujud pertanggungjawaban pemerintah terhadap masyarakat. sejak tahun 2003, Deputi Pengawasan Bidang Penyelenggaraan Keuangan Daerah mengembangkan Sistem Informasi Manajemen Daerah (SIMDA) keuangan berfungsi dan bertujuan dengan membantu pemerintah daerah untuk membangun dan menggunakan sistem informasi keuangan dan kinerja untuk tata kelola yang baik termasuk pengendalian transaksi dan informasi yang memadai.

Guna mewujudkan praktik pengelolaan keuangan daerah yang cepat, Seluruh Perangkat Daerah dihimbau untuk menerapkan aplikasi SIMDA keuangan berbasis komputer. Namun dalam pengoperasian Aplikasi SIMDA keuangan ini masih terkendala karena adanya faktor jaringan, kurang memadainya perangkat komputer yang disediakan sehingga tidak sesuai dengan konversi komputer yang diinginkan dalam aplikasi SIMDA Keuangan, kuranganya skill tenaga opeartor dalam mengoperaskan aplikasi SIMDA dan dampakanya akan mengalami kesulitan dalam proses penginputan data, penelaahan akun yang kadangkala keliru diinput dan data terkesan disesuaikan saja sehingga hasil yang disajikan kurang akurat walaupun secara jumlah dan nilainya sesuai dengan Laporan Realisasi Anggaran.

\subsection{Rumusan Masalah}

Berdasarkan latar belakang tersebut maka yang menjadi pokok permasalahan dalam penelitian ini adalah

1. Bagaimana sistem dan prosedur pelaporan keuangan Pemerintah Daerah pada Badan Pengelola Keuangan dan Aset Daerah Kabupaten Musi Banyuasin? 
2. Apakah penggunaan Aplikasi Sistem Informasi Manajemen Daerah (SIMDA) keuangan membantu dalam menyajikan laporan keuangan pemerintah daerah pada Badan Pengelola Keuangan dan Aset Daerah Kabupaten Musi Banyuasin dengan tepat waktu, akurat dan relevan.

\subsection{Tujuan Penelitian}

Tujuan dari penelitian ini yaitu untuk mengetahui sistem dan prosedur pengelolaan keuangan Pemerintah Daerah dengan menggunakan Aplikasi Sistem Informasi Manajemen Daerah (SIMDA) dalam penyusunan laporan laporan keuangan pada Badan Pengelola Keuangan dan Aset Daerah Kabupaten Musi Banyuasin.

\section{Tinjauan Pustaka}

\subsection{Tujuan dan Fungsi Sistem Informasi Manajemen Untuk Pengendalian Intern}

Sistem Pengendalian Intern Pemerintah (SPIP) dalam PP Nomor 60 Tahun 2008 tentang SPIP adalah proses yang integral pada tindakan dan kegiatan yang dilakukan secara terus menerus oleh pimpinan dan seluruh pegawai untuk memberikan keyakinan memadai atas tercapainya tujuan organisasi melalui kegiatan yang efektif dan efesien, keandalan pelaporan keuangan, pengamanan aset negara, dan ketaatan terhadap peraturan perundang-undangan.

Fungsi dari sistem tidak terbatas pada pihak manajemen saja, melainkan juga bagi organisasi secara keseluruhan, yaitu menciptakan pengendalian intern. Fungsi pengendalian intern, antara lain :

1. Meningkatkan produktivitas serta penghematan dalam hal biaya di dalam organisasi

2. Meningkatkan kualitas dari sumber daya manusia dikarenakan unit sistem kerja akan lebih terkoordinasi serta sistematis

3. Mempermudah pihak manajemen dalam melakukan pengawasan, perencanaan, pengarahan serta pendelegasian kinerja pada semua departemen yang mempunyai koordinasi dan hubungan.

4. Meningkatkan efisiensi serta efektivitas data yang lebih realtime dan akurat.

Tujuan Pengendalian Intern adalah : 
1. Tujuan perusahaan yang ditetapkan akan dapat dicapai.

2. Laporan keuangan yang dihasilkan perusahaan dapat dipercaya

3. Kegiatan perusahaan sejalan dengan hukum dan peraturan yang berlaku.

\subsection{Konsep Sistem dan Prosedur}

\subsubsection{Defenisi Sistem dan Prosedur}

Sistem menurut Susanto dalam Yulia Djahir dan S.M. Dewi Pratita (2015:6), adalah kumpulan/grup dari subsistem/bagian/komponen apapun baik fisik ataupun nonfisik yang saling berhubungan satu sama lain dan bekerjasama secara harmonis untuk mencapai tujuan. Sedangkan menurut Kamus Besar Bahasa Indonersia (2008) prosedur adalah serangkaian aksi yang spesifik, tindakan atau operasi yang harus dijalankan atau dieksekusi dengan cara yang baku (sama dari keadaan yang sama aktifitas atau kegiatan yang dilakukan secara berulang-ulang dengan cara yang sama.

Manfaat suatu prosedur menurut Mulyadi (2014: 6) adalah :

a. Lebih memudahkan dalam menentukan langkah-langkah kegiatan dimasa akan datang.

b. Merubah pekerjaan yang berulang-ulang menjadi rutin dan terbatas, sehingga menyederhanakan pelaksanaan dan selanjutnya mengerjakan yang perlunya saja.

c. Adanya suatu petunjuk/program kerja yang jelas dan harus dipatuhi untuk seluruh pelaksanaan.

d. Membantu dalam usaha meningkatkan produktifitas kerja yang efektif dan efisien.

e. Mencegah terjadinya penyimpangan dan memudahkan dalam pengawasan.

\subsection{Konsep Sistem Informasi Manajemen Daerah}

\subsubsection{Pengertian Sistem Informasi Manajemen Daerah}

Aplikasi SIMDA merupakan aplikasi database yang bertujuan untuk mempermudah pengelolaan keuangan daerah di lingkungan Satuan Kerja Perangkat Daerah (SKPD). Aplikasi SIMDA dikembangkan dengan memperhatikan dan mengimplementasikan Sistem Pengendalian Intern 
Pemerintah (SPIP), oleh sebab itu pengendalian terhadap aplikasi menjadi suatu keharusan untuk menjadi pedoman bagi pemerintah daerah dalam mengimplementasikan Aplikasi SIMDA untuk menghasilkan Laporan Keuangan Pemerintah Daerah (LKPD)

\subsubsection{Perkembangan Aplikasi Sistem Informasi Manajemen Daerah}

Perkembangan SIMDA Keuangan mengalami empat tahapan perubahan, yaitu : 1).SIMDA Ver. 1.0 ; 2).SIMDA Ver. 2.0 ;3).SIMDA Ver. 2.1 dan SIMDA Ver 2.7. Dasar pengembangan aplikasi SIMDA Keungan Ver 2.7 berbasis akrual antara lain, PP 71 Tahun 2010 Tentang Standar Akuntansi Pemerintahan Peraturan Menteri Keuangan Nomor 238 Peraturan Menteri Keuangan Nomor 05 2011 Tentang Pusat. Permendagri Nomor 64 Tahun 2013 Tentang Pedoman Penerapan Standar Akuntansi Pemerintahan Berbasis akrual pada Pemerintah Daerah. Output aplikasi antara lain APBD beserta perubahannya, SPM, SP2D, jurnal transaksi akrual, buku besar, neraca, laporan operasional, laporan perubahan ekuitas, Laporan Realisasi Anggaran, Laporan perubahan SAL, Laporan Arus Kas, serta pertanggungjawaban, mekanisme dan output penganggaran, penatausahaan, dan pertanggungjawaban berpedoman pada Permendagri 13 Tahun 2006 Nomor 59 Tahun 2007, Nomor 55, Nomor 21 dan seterusnya proses dan output akuntansi berpedoman pada PP 71 Tahun 2010, PMK 238 Tahun 2011 dan Permendagri Nomor 64 Tahun 2013.. Perubahan perkembangan Aplikasi SIMDA ke versi 2.7 karena adanya perubahan peraturan, penyesuaian kode dan akun yang tidak sesuai lagi dengan mata anggaran yang harus diinput dalam Aplikasi SIMDA yang sesuai dengan yang kebutuhan yang dianggarkan.

Output yang dihasilkan dari SIMDA Keuangan adalah :

1. Penganggaran, meliputi ;

a) Rencana Kerja Anggaran (RKA)

b) Dokumen Pelaksanaan Anggaran (DPA)

c) Surat Penyediaan Dana (SPD)

2. Penatausahaan atau Perbendaharaan, meliputi ;

a) Surat Permintaan Pembayaran (SPP)

b) Surat Perintah Membayar (SPM) 
c) Surat Perintah Pencairan Dana (SP2D)

d) Surat Tanda Setoran (STS)

e) Register

f) Surat pengendalian lainnya.

3. Akuntansi dan Pelaporan, meliputi ;
a) Jurnal
b) Buku besar
c) Buku pembantu
d) Laporan realisasi anggaran
e) Laporan arus kas
f) Neraca.

4. Program Aplikasi SIMDA Keuangan didukung dengan :
a) Buku manual sistem dan prosedur penganggaran
b) Buku manual sistem dan prosedur penatausahaan
c) Buku manual sistem dan prosedur akuntansi dan pelaporan
d) Buku pedoman pengoperasian aplikasi SIMDA Keuangan.

\section{Fungsi Program Aplikasi SIMDA :}

1. Membantu Pemerintah Daerah dalam melaksanakan pengelolaan keuangan daerah (penganggaran, pelaksanaan, pertanggungjawaban)

2. Menyusun laporan keuangan lebih efisien dan akurat

3. Menyimpan data keuangan untuk keperluan manajemen lainnya

4. Menyajikan informasi yang akurat secara efektif dan efisien.

5. Mempermudah proses audit

\subsection{Konsep Laporan Keuangan Pemerintah Daerah}

\subsubsection{Pengertian Laporan Keuangan Pemerintah Daerah}

Peraturan Menteri Dalam Negeri Nomor 13 Tahun 2016 tentang Pedoman Pengelolaan Keuangan Daerah, dalam ketentuan umumnya menyebutkan bahwa yang dimaksud dengan keuangan daerah adalah semua hak dan kewajiban daerah dalam rangka penyelenggaraan pemerintah daerah yang dapat dinilai dengan uang termasuk didalamnya segala bentuk kekayaan yang berhubungan dengan hak dan kewajiban daerah tersebut. 


\subsubsection{Tujuan Laporan Keuangan}

Berdasarkan Standar Akuntasi Keuangan (2002:4) tujuan laporan keuangan adalah:

1. Menyediakan informasi yang menyangkut posisi keuangan, kinerja, serta perubahan posisi keuangan suatu perusahaan yang bermanfaat bagi sejumlah besar pemakai dalam pengambilan keputusan ekonomi.

2. Laporan keuangan yang disusun untuk tujuan ini memenuhi kebutuhan bersama sebagian besar pemakai. Namun demikian, laporan keuangan tidak menyediakan semua informasi yang mungkin dibutuhkan pemakai dalam pengambilan keputusan ekonomi karena secara umum menggambarkan pengaruh keuangan dan kejadian di masa lalu.

3. Laporan keuangan juga menunjukkan apa yang telah dilakukan manajemen (stewardship) atau pertanggunggjawaban manajemen atas sumber daya yang dipercayakan kepadanya.

\subsubsection{Fungsi Laporan Keuangan}

Adapun beberapa fungsi lainnya dari laporan keuangan, diataranya ialah sebagai berikut:

1. Sebagai Media Review

Financial statement bisa menyajikan informasi atau data yang komprehensif mengenai kedudukan keuangan perusahaan.

2. Sebagai Pedoman Membuat Keputusan

Salah satu fungsi paling penting dalam pembuatan laporan tentang keadaan keuangan perusahaan yaitu sebagai media pertimbangan dalam pengambilan keputusan penting untuk perusahaan.

3. Membantu Menciptakan Strategi Baru

Financial statement juga bisa digunakan dalam membuat strategi baru oleh perusahaan dalam usaha menaikan performa usahanya.

4. Meningkatan Kredibilitas Perusahaan

Perusahaan yang membuat financial statement akan menunjukkan bahwa perusahaan itu sudah menerapkan sebuah sistem perekapan data yang terpercaya, akurat, serta tidak sembarangan dalam pengambilan keputusan. 


\section{Metodologi Penelitian}

\subsection{Lokasi dan Waktu Penelitian}

Lokasi penelitian ini adalah Badan Pengelola Keuangan dan Aset Daerah Kabupaten Musi Banyuasin, yang berlokasi di Jalan Kolonel Wahid Udin Lingkungan VII Nomor 240 Kelurahan Serasan Jaya Kecamatan Sekayu Kabupaten Musi Banyuasin. Penelitian ini dilakukan selama 3 bulan yaitu dari bulan Nopember 2020 s.d. Januari 2021

\subsection{Jenis dan Sumber Data Penelitian}

Jenis dan sumber data yang digunakan dalam penelitian ini adalah data primer. Data primer diproleh dari wawancara operator Aplikasi SIMDA dalam penyusunan laporan keuangan Pemerintah Daerah pada Badan Pengelola Keuangan dan Aset Daerah Kabupaten Musi Banyuasin.

\subsection{Teknik Pengumpulan Data}

Pada penelitian ini Penulis mengadakan penelitian langsung yaitu dengan cara wawancara dengan administrator dan operator Aplikasi SIMDA pada Badan Pengelola Keuangan dan Aset daerah Kabupaten Musi Banyuasin.

\subsection{Teknik Analisis Data}

Teknik analisis data yang dalam penelitian ini adalah teknik analisis kualitatif. Teknik analisis kualitatif dilakukan dengan cara menggambarkan kenyataan atau keadaan-keadaan suatu objek dalam bentuk uraian kalimat berdasarkan keterangan-keterangan dari pihak-pihak yang berhubungan dengan penelitian ini. Hasil analisis tersebut kemudian diinterprestasikan guna memberikan gambaran yang jelas terhadap permasalahan yang diajukan.

\section{Pembahasan}

Hasil wawancara yang diperoleh dari admin operator Aplikasi SIMDA, sebelum pengoperasian aplikasi SIMDA, yang harus dilakukan adalah pemahaman penggunaan Aplikasi SIMDA secara menyeluruh bagaimana sistem dan prosedur yang diterapkan sehingga dalam penginputan data ke dalam Aplikasi SIMDA sesuai dengan mata pasal dalam anggaran dengan laporan realisasi anggaran. Langkah pertama dalam pengelolaan aplikasi SIMDA adalah 
identifikasi data, selanjutnya pemahaman dan penginputan data yang disesuaikan dengan kode dan mata anggaran dalam Aplikasi SIMDA.

\subsection{Analisis Penerapan Aplikasi Sistem Informasi Manajemen Daerah (SIMDA)}

Sistem Informasi Manajemen Daerah (SIMDA) digunakan untuk penginputan laporan keuangan yang berhubungan dengan :

1. Rencana Kerja Anggaran (RKA)

2. Dokumen Pelaksana Anggaran (DPA)

3. Surat Penyedia Dana (SPD)

4. Surat Permintaan Pembayaran (SPP)

5. Surat Perintah Membayar (SPM)

6. Surat Perintah Pencairan Dana (SP2D)

Cara kerja aplikasi SIMDA keuangan terbagi ke dalam 3 (tiga) bagian yang digambarkan dalam bentuk arus dokumen (Fowchart) dibawah ini, yaitu output yang dihasilkan oleh bagian :

\section{Penganggaran}

Bagian anggaran bertanggungjawab untuk menyusun rencana kerja anggaran (RKA), dokumen pelaksana anggaran (DPA), serta surat penyedia dana (SPD 1). Rencana Kerja Anggaran

Bagian ini menyusun rencana kerja anggaran yang diperoleh dari informasi dan data dari seluruh perangkat daerah pemerintah daerah kabupaten Musi Banyuasin. 
Jurnal Ilmiah Akuntansi Rahmaniyah (JIAR)

Vol. 4 No.2, Juni 2021, 141 - 159

Ermawijaya

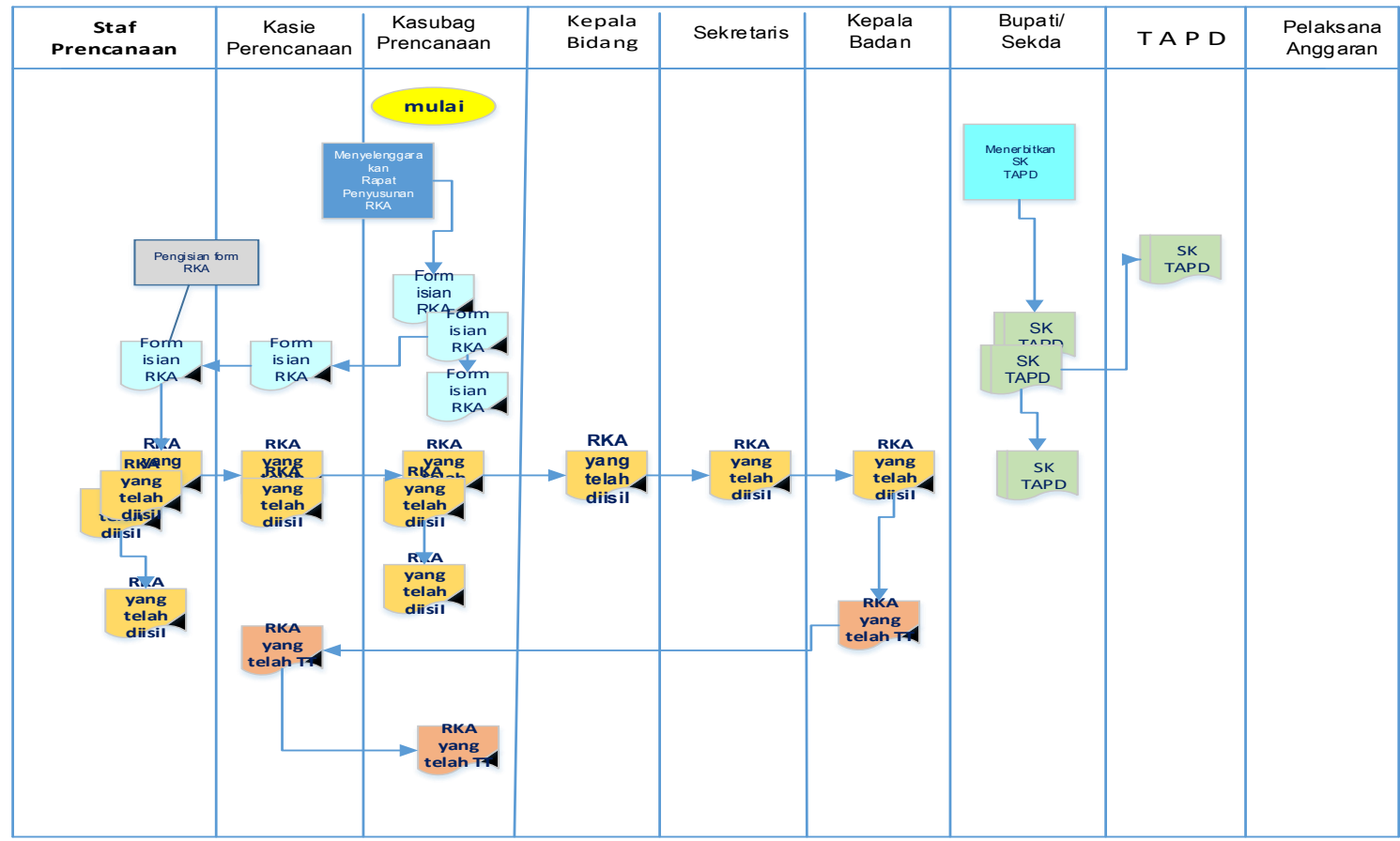

Gambar 4.1

Flowchart Penyusunan Rencana Kerja Anggaaran (RKA)

Badan Pengelola Keuangan dan Aset Daerah Kabupaten Musi Banyuasin

2). Dokumen Pelaksana Anggaran (DPA)

Bagian anggaran selanjutnya setelah adanya Surat keputuasan TAPD

diterbitkan, memeriksa salisan dokumen pelaksana anggaran (diteliti dan disesuaikan). 
Jurnal Ilmiah Akuntansi Rahmaniyah (JIAR)

Vol. 4 No.2, Juni 2021, 141 - 159

Ermawijaya

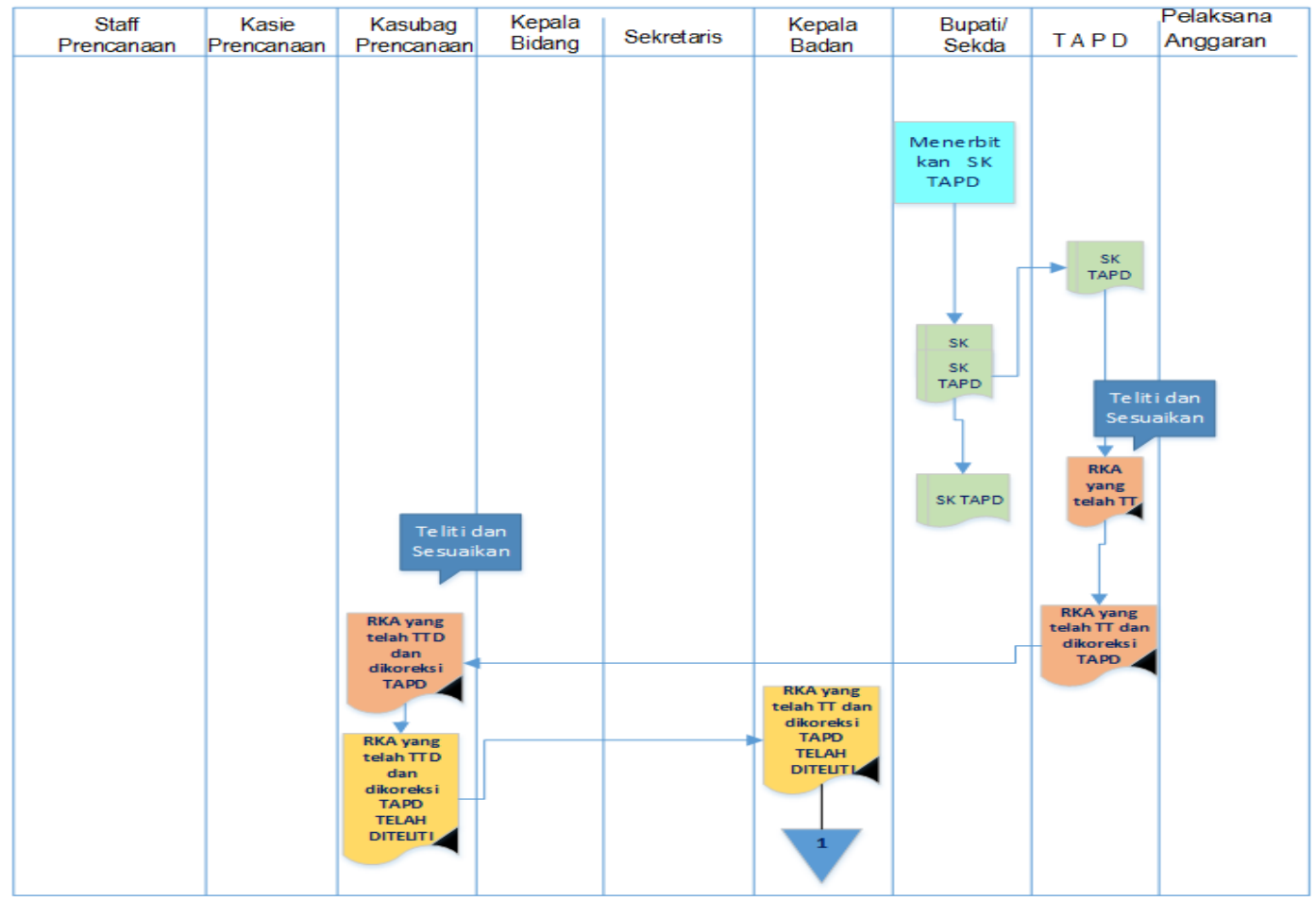

Gambar 4.2

Flowchart Penyusunan Dokumen Pelaksana Anggaran (DPA)

Badan Pengelola Keuangan dan Aset Daerah Kabupaten Musi Banyuasin

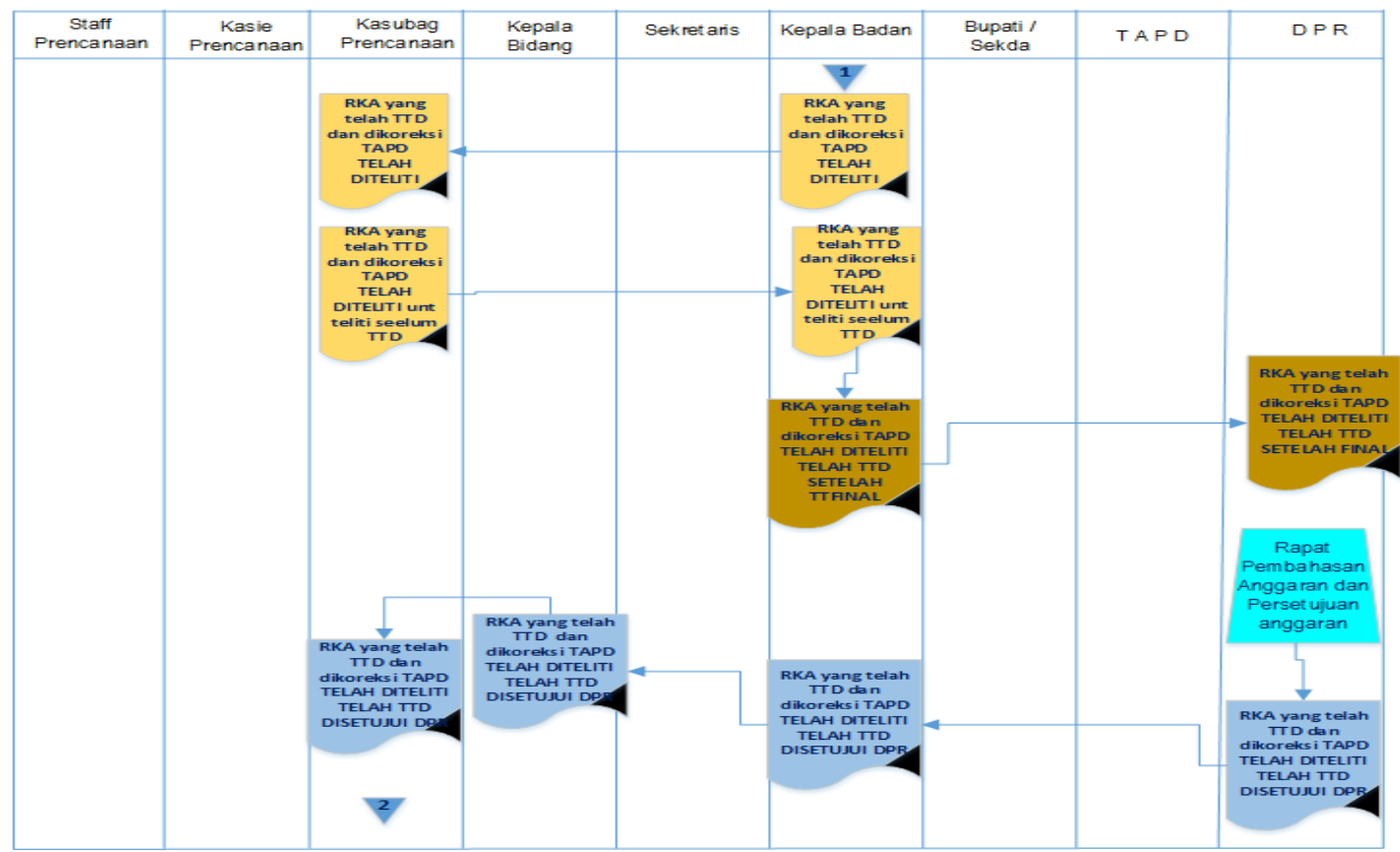

Gambar 4.2 (Lanjutan)
Flowchart Penyusunan Dokum en Pelaksana Anggaran (DPA)

Badan Pengelola Keuangan dan Aset Daerah Kabupaten Musi Banyuasin 
Jurnal Ilmiah Akuntansi Rahmaniyah (JIAR)

Vol. 4 No.2, Juni 2021, 141 - 159

Ermawijaya

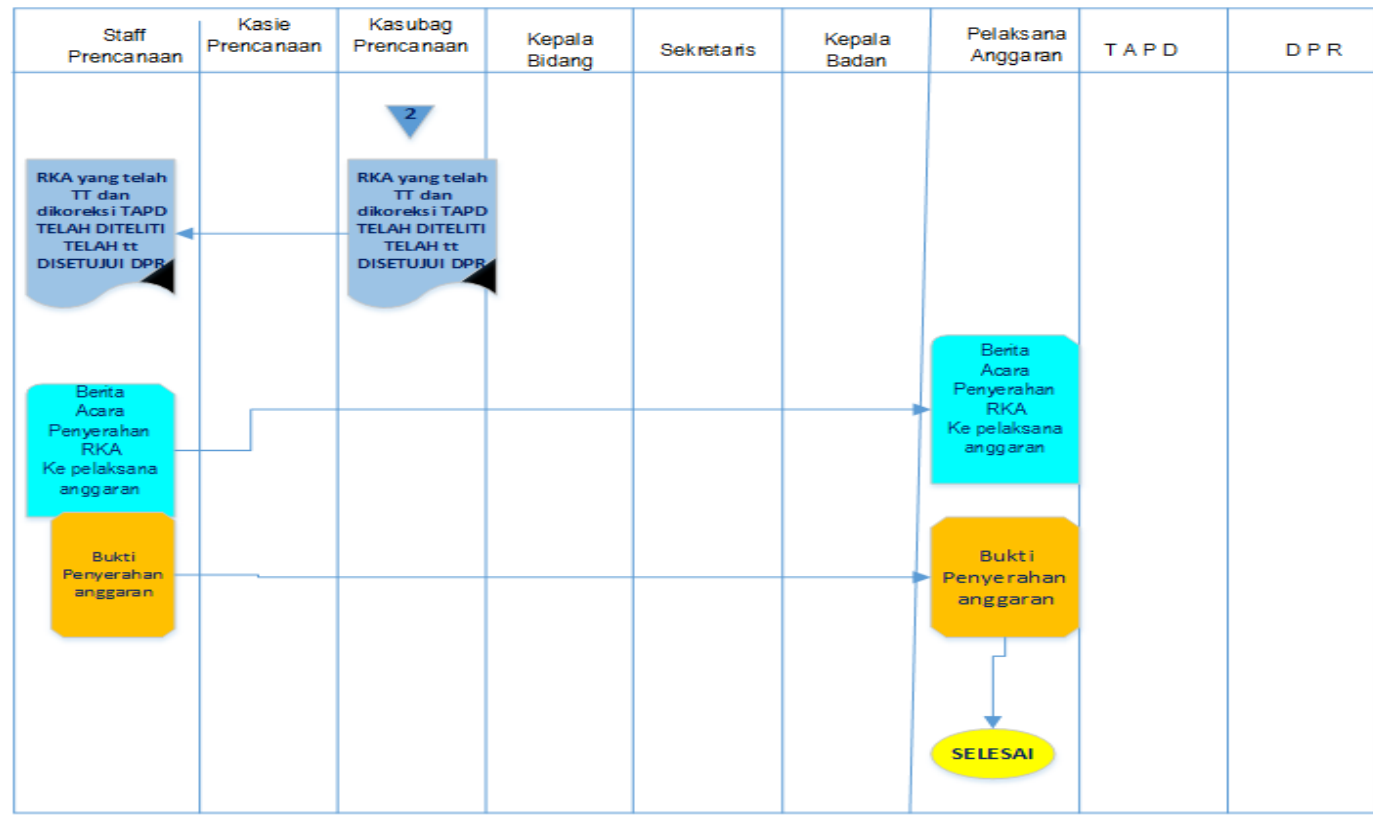

Gambar 4.2 (Lanjutan)

Flowchart Penyusunan Dokumen Pelaksana Anggaran (DPA)

Badan Pengelola Keuangan dan Aset Daerah Kabupaten Musi Banyuasin

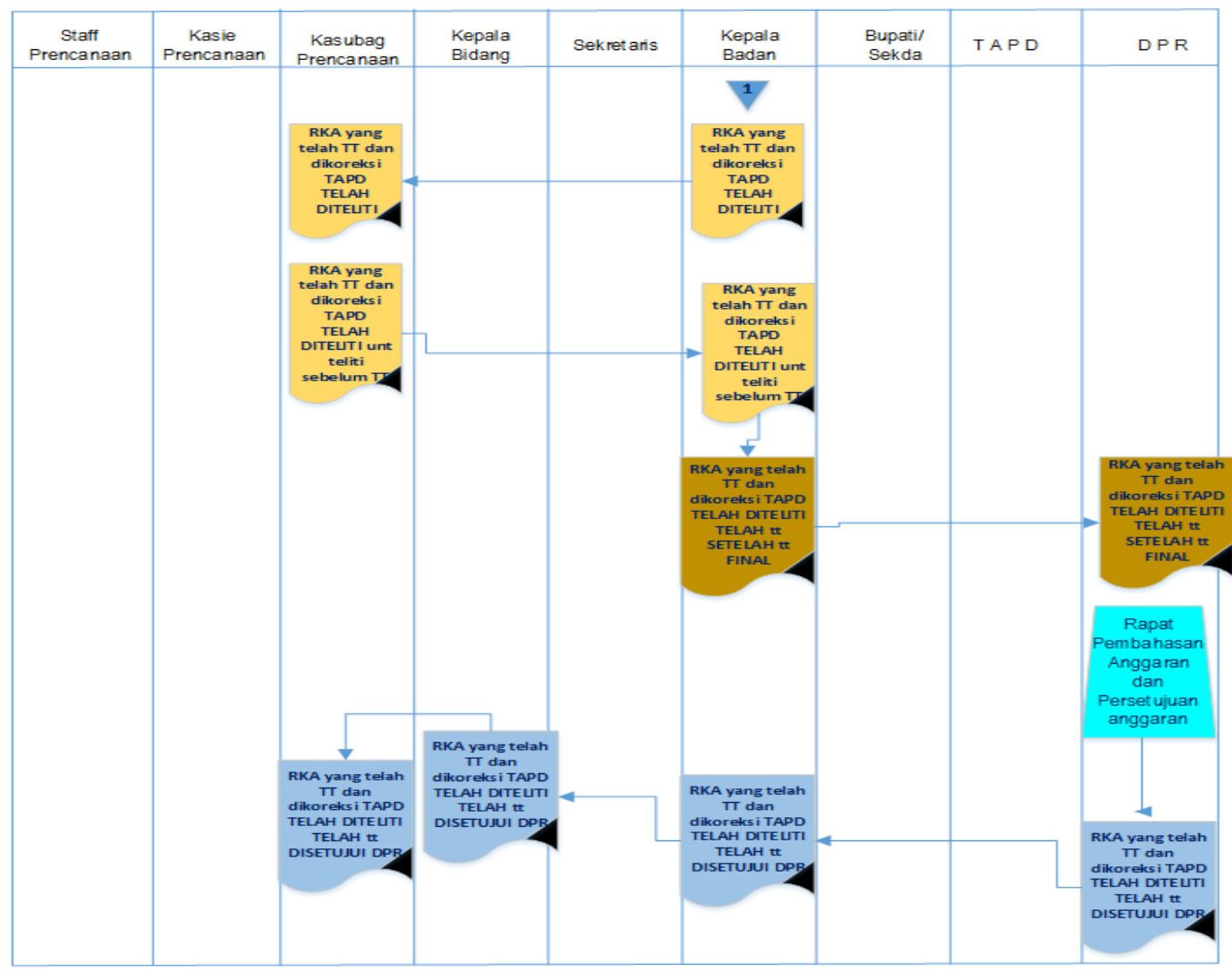

Gambar 4.2 (sel esai)

Flowchart Penyusunan Dokumen Pelaksana Anggaran (DPA)

Badan Pengelola Keuangan dan Aset Daerah Kabupaten Musi Banyuasin 
3). Surat Penyediaan Dana (SPD)

Bagian ini berfungsi menyiapkan surat penyedia anggaran, sebagaimana flowchart nerikut ini :

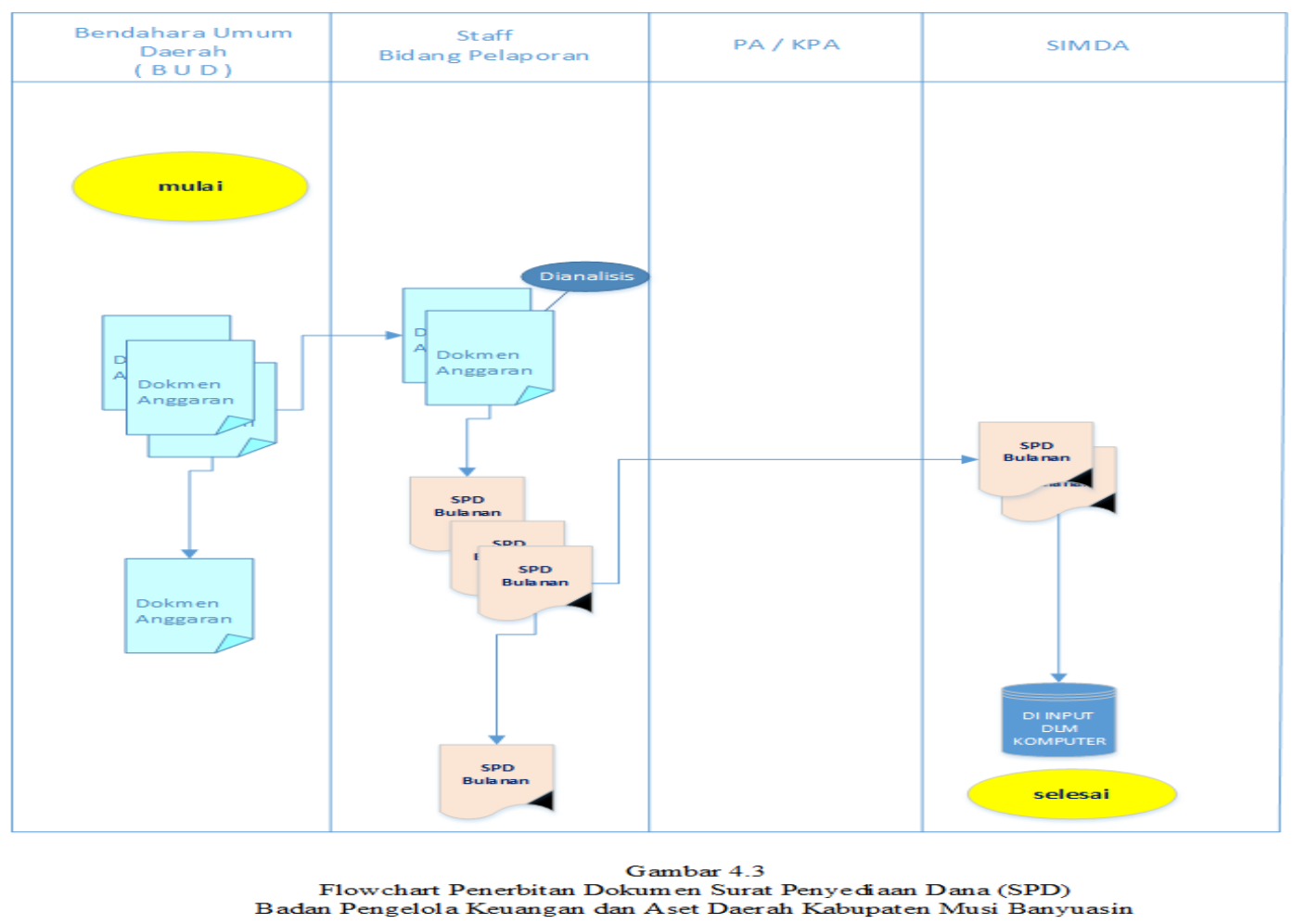

4). Surat Perintah Pencairan (SPP) dan Surat Perintah Membayar (SPM)

Bagian ini berfungsi menyiapkan surat perintah pencairan dan surat perintah membayar, sebagaimana flowchart berikut ini 
Jurnal Ilmiah Akuntansi Rahmaniyah (JIAR)

Vol. 4 No.2, Juni 2021, 141 - 159

Ermawijaya

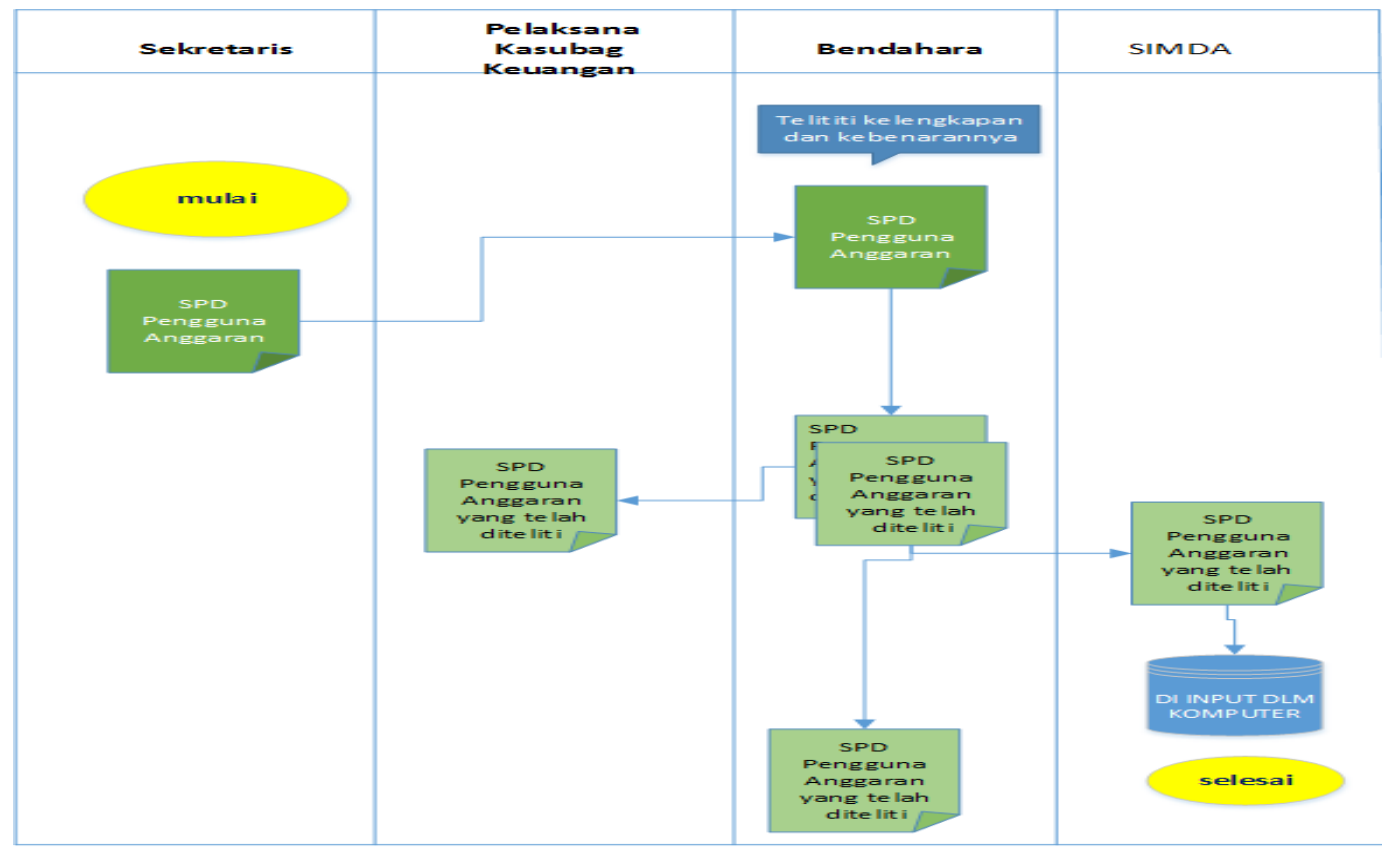

Gambar 4.4
Flowchart Prosedur Penerbitan Surat Perintah Pencairan (SPP)

Badan Pengelola Keuangan dan A set Daerah Kabupaten Musi Banyuasin 
5). Surat Perintah Pencairan Dana (SP2D)

Bagian ini berfutugas menyiapkan surat perintah pencairan dana (SP2D) setelah Surat perintah membayar di tandatangai. Berikut ini Flowchart surat perintah pencairan dana (SP2D) :

Prosedur Penerbitan SP2D

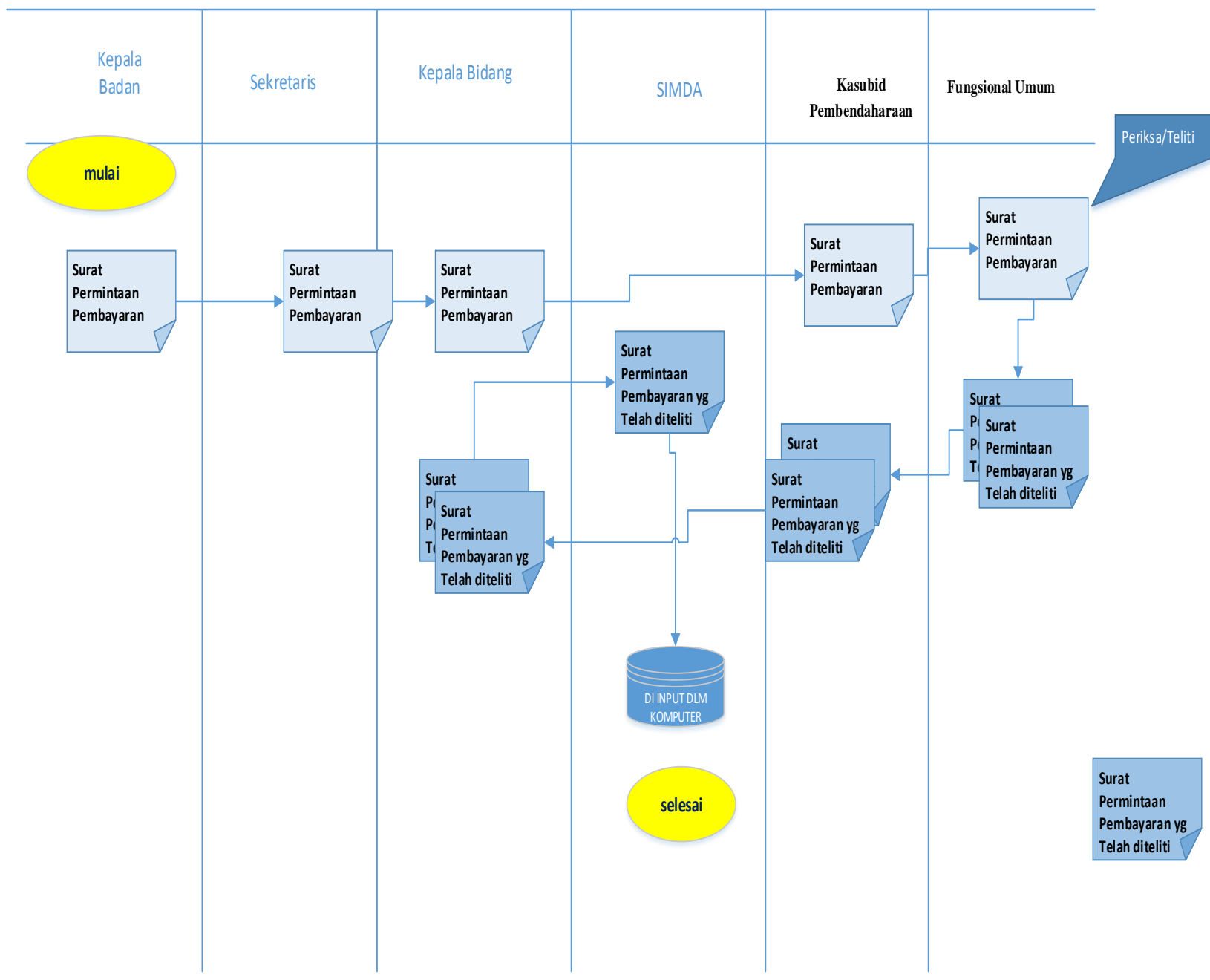

Gambar 4.5

Flowchart Surat Perintah Pencairan Dana (SP2D)

BPKAD Kabupaten Musi Banyuasin

\section{Penatausahaan atau Perbendaharaan}

Bagian Penatausahaan atau perbendaharaan mempunyai tugas membuat surat permintaan pembayaran (SPP), surat perintah membayar (SPM) dan surat perintah pencairan dana (SP2D). 


\section{Akuntansi dan Pelaporan}

Bidang akuntansi dan pelaporan mempunyai tugas dan bertanggung jawab untuk menyusun laporan keuangan pemerintah daerah seperti, Laporan Realisasi Anggaran (LRA), Neraca, dan Catatan Akhir Laporan Keuangan Akhir Keuangan dari penginputan dalam aplikasi SIMDA Keuangan.

Setiap bagian bertanggungjawab atas tugasnya masing-masing, Bagian penatausahaan bertanggungjawab untuk menyusun surat permintaan pembayaran (SPP), surat perintah membayar (SPM), surat perintah pencairan dana (SP2D) serta surat surat lainnya, sedangkan bagian akuntansi bertanggungjawab untuk menyusun laporan keuangan. Secara keseluruhan jika dilihat dari sistem dan prosedur pengelolaan keuangan telah dilaksanak dengan cukup baik.

Namun mengoperasikan aplikasi SIMDA terdapat kendala yang masih dihadapi oleh admin operator aplikasi SIMDA pada Badan Pengelola Keuangan dan Aset Daerah Kabupaten Musi Banyuasin, diantaranya adalah:

1. Lemahnya pendukung sistem ini terutama jaringan (listrik dan telekomunikasi) yang mendukung terkoneksinya admin operator Aplikasi SIMDA dengan seluruh perangkat daerah lainnya sehingga dalam proses penginputan data menjadi terlambat dan berpengaruh dalam penyelesaian pelaporan.

2. Perangkat pendukung penerapan Aplikasi SIMDA keuangan pada Komputer milik Perangkat Daerah kurang mendukung karena perbedaan versi komputer lama kurang sesuai dengan akan diterapkan dalam Aplikasi SIMDA keuangan, sehingga dalam pengoperasian aplikasi SIMDA keuangan di olah kembali secara manual agar sesuai dengan menu-menu dalam aplikasi SIMDA keuangan.

3. Kurangnya keahlian (skill) sumber daya manusia dalam mengelola Sistem Informasi Manajemen Daerah (SIMDA) keuangan, yang mengakibatkan keterlambatan dan kekeliruan dalam penginputan data dalam Aplikasi SIMDA.

Dari ketiga kendala diatas akan berpengaruh pada proses entry data. dimulai sejak awal pengisian data kurang lancar dan kurang teliti, maka proses dalam tahap mengoreksi data akan bertambah panjang, data sorting akan lamban, 
dan akhirnya tujuan organisasi Pemrosesan Data Elektronik (PDE) untuk menghasilkan informasi tepat pada waktunya tidak akan tercapai.

Upaya-upaya yang perlu dilakukan dalam penerapan aplikasi Sistem Informasi Manajemen Daerah (SIMDA) keuangan dalam menghasilkan laporan keuangan tepat waktu dan akurat :

1. Harus adanya penyempurnaan jaringan, seperti disediakannya perangkat komputer yang cukup dan memadai, karena Badan Pengelola Keuangan dan Aset Daerah adalah Server nya pelaporan keuangan Perangkat Daerah (PD) di seluruh Kabupaten Musi Banyuasin.

2. Peningkatan versi komputer yang lebih canggih akan sangat membantu dan mendukung efesiensi pengelolaan laporan keuangan dalam pengoperasian Aplikasi SIMDA Keuangan.

3. Perlu adanya peningkatan bimbingan teknis dan pembinaan bagi administrator dalam pengoperasian Aplikasi SIMDA, sehingga akan sangat mendukung dalam mempercepat proses penginputan data, proses dan pelaporan dan kesalahan yang terjadi dapat diminimalisir.

Sistem Informasi Manajemen Daerah (SIMDA) keuangan diguanakan dengan maksud dapat menghasilkan informasi yang akurat, tepat waktu, dan relevan yang dapat dijadikan alat control atau sebagai media pengendalian intern dalam penyusunan laporan keuangan.

Dari hasil penelitian pada BPKAD Kabupaten Musi Banyuasin, ditemukan beberapa kualitas informasi yang dihasilkan dari penerapan SIMDA Keuangan.

a) Akurasi, dalam penggunaan SIMDA Keuangan keluhan tentang sistem ada beberapa yang menjadi masalah namun bisa diminimalisir dengan beberapa upaya supaya sistem nantinya bisa berjalan secara optimal.

b) Ketetapan Waktu, dengan adanya SIMDA Keuangan, BPKAD Kabupaten Musi Banyuasin dapat menyajikan laporan keuangan tepat waktu.

c) Relevan, SIMDA Keuangan relevan karena data sudah terprogram langsung kepada administror pengelola laporan akuntansi yang disusun oleh seluruh perangkat daerah di kabupaten Musi Banyuasin, sehingga akan lebih mudah dalam penginputan data. 


\section{V.Simpulan}

Berdasarkan permasalahan dan pembahasan diatas dapat disimpulkan bahwa :

1. Sistem dan prosedur pengelolaan keuangan pada Badan Pengelola Keuangan dan Aset Daerah Kabupaten Musi Banyuasin dilihat dari alur atau flowchart Penganggaran, analisis penatausahaan, Akuntansi dan pelaporan sudah berjalan dengan cukup baik, karena masing-masing bagian yang bertanggungjawab telah menjalankan fungsinya sesuai dengan petunjuk dalam nomenklatur pengelolaan pelaporan keuangan bagi pemerintah daerah khususnya.

2. Dalam Pelaporan keuangan, sejak tahun 2003 Pemerintah Daerah Kabupaten Musi Banyuasin sudah menggunakan aplikasi berbasis komputer dalam pelaporan keuangan, tetapi laporan keuangan dari perangkat daerah masih i input secara manual dan belum terintegrasi pada pelaporan keuangan Badan Pengelola Keuangan dan Aset Daerah Kabupaten Musi Banyuasin. Untuk itu aplikasi SIMDA setelah beberapa kali mengalami perubahan versi maka aplikasi Sistem Informasi Manajemen Daerah (SIMDA) keuangan dari perangkat daerah sudah terintegrasi, namun dalam penginputan data ke dalam aplikasi SIMDA sering terkendala jaringan, spesikasi komputer yang tersedia tidak sesuai dengan menu dalam aplikasi SIMDA dan minimnya tenaga yang terampil dalam mengoperasikan apikasi SIMDA.

Upaya yang dilakukan Badan Pengelola Keuangan dan Aset Daerah Kabupaten Musi Banyuasin adalah melukukan peningkatan dan penambahan jaringan yang mampu dijangkau oleh selauruh perangkat daerah Kabupaten Musi Banyuasin, menyiapkan komputer sesuai dengan spesifikasi yang cukup sehingga pada saat penginputan data ke dalam aplikasi SIMDA tidak mengalami salah input data dan perlunya peningkatan skill bagi tenaga operator aplikasi SIMDA sehingga mempunyai kemampuan dan memudahkan dalam proses penyusunan pelaporan keuangan pada Badan Pengelola Keuangan dan Aset Daerah Kabupaten Musi Banyuasin.

\section{Daftar Pustaka}

Ikatan Akuntansi Indonesia. 2002. Standar Akuntansi Keuangan. Jakarta. Salemba Empa 
Kamus Besar Bahasa Indonesia.2008. Jakarta

Peraturan Pemerintah Nomor 60 Tahun 2008 tentang Sistem Pengendalian Inten Pemerintah.

Peraturan Pemerintah Nomor 71 Tahun 2010 tentang Standar Akuntansi Pemerintah,

Peraturan Menteri Dalam Negeri Nomor 13 Tahun 2016 tentang Pedoman Pengelolaan Keuangan Daerah

Undang-Undang Nomor 32 Tahun 2004 Tentang Pemerintah Daerah

Yulia Djahir dan S.M.Dewi Pratita.2015. Bahan Ajar Sistem Informasi Manajemen. Yogyakarta : Deepublish. 